This is the preprint version (before peer review). Please cite as:

Regilme S.S.F., Polat E.N. (2019) Right to Economic Dignity. In: Romaniuk S., Thapa M., Marton P. (eds) The Palgrave Encyclopedia of Global Security Studies.

Palgrave Macmillan, Cham

Latest online version:

DOI: https://doi.org/10.1007/978-3-319-74336-3 326-1

\title{
Right to Economic Dignity
}

Salvador Santino F. Regilme Jr.

$\&$

Elif Nisa Polat

History and International Studies, Institute for History, Leiden University, Netherlands

\section{Introduction}

The right to economic dignity is one of most important and concrete political-legal expressions that seek to protect human dignity. The right to economic dignity also refers to various socio-economic rights that include the right to housing, right to adequate standard of living, right to healthcare, right to social security, right to adequate food and water, among others. Whereas civil and political rights seek to guarantee the privileges accorded to human individuals as free members of a political community, the right to economic dignity posits that its bearers possess the privilege to enjoy various concrete material benefits that enable them to live a decent living standard.

Human dignity constitutes a quintessential place in the Charter of the United Nations as well as in the Universal Declaration of Human Rights in 1948, and it is widely considered as the most important value of the global human rights regime. The concept of dignity appears in various constitutional traditions of many states, particularly those that were established after World War II; for example, the German Basic Law (Grundgesetz) postulates that human dignity is its fundamental 'constitutive principle' (Grant 2013, 238). As the German philosopher Jürgen Habermas $(2010,464)$. argues, human rights may be considered as concrete specifications of human dignity as its foundational moral basis. In that sense, socioeconomic rights refer to the more concrete specifications of human dignity, and it posits that its bearers must have access to material social and economic benefits that enable them to actualize their dignity.

In practice, socio-economic rights can be enjoyed through a state-supported welfare and benefits system. In many ways, citizens in wealthier states with a robust welfare state tradition are more likely to enjoy a comprehensive set of socioeconomic benefits than those states that are not. While constitutionalizing socioeconomic rights may encourage states to entrench the language of economic dignity 
in the legal system, there are so many transnational and domestic variables that constrain ruling governments in actualizing such rights (Regilme 2014a).

\section{Global human rights instruments}

The relevance of economic rights in the design of the national and global institutional orders has been recognized since the early 20th century. After World War II, human rights conventions have been established in an effort to protect not only civil and political rights, but also economic, social and cultural rights.

After World War I, in an effort to protect the welfare of laborers, the international community established the International Labour Organization (ILO). Later, the ILO recognized a range of workers' rights in its Declaration of Philadelphia (1944), affirming that "all human beings... have the right to pursue both their material wellbeing and their spiritual development in conditions of freedom and dignity, of economic security and equal opportunity" (Article 2). The ILO has adopted numerous economic rights conventions on forced labor, child labor, freedom of association and collective bargaining, non-discrimination, and indigenous and tribal population rights. The ILO now functions as a specialized agency of the United Nations to which all 193 UN member states belong.

After World War II, the global human rights regime began incorporating economic, social, and cultural rights - alongside civil and political rights. These rights are indicated in the two binding international covenants: The International Covenant on Civil and Political Rights (ICCPR, 1966) and the International Covenant on Economic, Social, and Cultural Rights (ICESCR, 1966) supplementing the Universal Declaration for Human Rights (UDHR, 1948). Other binding agreements, which expand on the rights contained in the Universal Declaration, include The International Convention on the Elimination of All Forms of Racial Discrimination (CEDAW, 1965), Convention on the Elimination of All Forms of Discrimination against Women (1979), the Convention on the Rights of the Child (1989), International Convention on the Protection of the Rights of All Migrant Workers and Members of Their Families (1990), Convention on the Rights of Persons with Disabilities (2006).

Although the UDHR does not directly create legal obligations for states, it has had a profound effect on the development of the international human rights regime. The UDHR is particularly remarkable for introducing the idea of 'dignified existence', which encourages the realization of the economic, social and cultural rights indispensable for dignity (Article 22). To provide the necessary economic conditions for all, the UDHR acknowledges 'the right to just and favorable remuneration' as being necessary to ensure 'an existence worthy of human dignity' (Article 23). More specifically, the UDHR emphasizes the right to adequate standards of living for everyone, for the health and well-being of himself and of his family, including food, housing and medical care and necessary social services and the right to security in the event of unemployment, sickness, disability, widowhood, old age or other lack of livelihood in circumstances beyond his control' (Article 25). It also incorporates 'welfare rights' such as social security, work, rest and leisure, an adequate standard of living, education, and culture (Articles 22-7). 
Global human rights norms are primarily enshrined in the two covenants of the UDHR. The Preambles of ICESCR and ICCPR both declare that the rights they enshrine, 'derive from the inherent dignity of the human person'. In regard to economic rights, examples of rights under the ICESCR include the right to work (Article 6) on fair and favorable conditions (Article 7), the right to form and join trade unions and strike (Article 8), the right of everyone to an adequate standard of living for himself and his family, including adequate food, clothing and housing, and to the continuous improvement of living conditions (Article 11), the right to education (Article 13), the obligation to protect children and young persons from economic and social exploitation (Article 10). The ICESCR creates legally binding international obligations to those states that have agreed to be bound by the standards contained in it. As of April 2018, 167 States are parties to the Covenant.

State obligations with respect to these rights arise from Article 2 of the ICESCR, which affirms that: "Each State Party to the present Covenant undertakes to take steps, individually and through international assistance and co-operation, especially economic and technical, to the maximum of its available resources, with a view to achieving progressively the full realization of the rights recognized in the present Covenant by all appropriate means, including particularly the adoption of legislative measures" (italics added). The ICESCR thus extends the responsibility for realizing these rights beyond national borders, while recognizing the practical difficulties posed by demands for full realization, especially for poor countries. Even so, the Committee on Economic, Social and Cultural Rights (CESCR) underlined that states must show that they have used 'all appropriate means' and that they have acted 'to the maximum of [their] available resources' to implement the provisions 'progressive realization' (Chenwi 2013).

While setting the standards through legislation is obviously essential, the effectiveness of enforcement by the courts is crucial in the actualization of social and economic rights. To this end, the ICCPR contains an additional protection in the form of an individual complaints mechanism, whereby individuals can submit a complaint directly to the Human Rights Committee. Also, the Economic and Social Council (ECOSOC) built up the Committee on Economic, Social and Cultural Rights (CESCR) in 1985 to monitor compliance of the ICESCR by the State Parties. The Committee adopted an Optional Protocol, entered into force in 2013, providing the competence to receive and consider communications from individuals.

\section{Regional human rights instruments}

The adoption of the European Convention on Human Rights in 1950 paved the way for the creation of regional standards to protect human dignity. The American Convention on Human Rights (Protocol of San Salvador, 1967) was subsequently followed by the adoption of the African Charter on Human and Peoples' Rights in 1981. Today, the Americas, Africa and Europe have developed progressive regional human rights instruments including complaints mechanisms through which individuals can seek justice and reparation for human rights violations committed by a State party. Yet, such mechanisms have not been developed in the Middle East and Asia.

In Europe, the members of the Council of Europe adopted The European Social Charter (ESC) in 1961 to promote and protect economic and social rights. Thereafter, the European Union has put down the economic rights in 2000 in the 
Charter of Fundamental Rights of the European Union. The Article I of the Charter states that "human dignity is inviolable", and ensures the right to engage in work and to pursue a freely chosen or accepted occupation (Article 15), the freedom to conduct a business (Article 16), the right to property (Article 17), the right of collective bargaining and action (Article 28), the right to working conditions which respect his or her health, safety and dignity (Article 31) and prohibition of child labor and protection of young people at work (Article 32). It also reflects the principles derived from the case law of the Court of Justice and the European Court of Human Rights. The Charter is now a part of the Treaty of Lisbon, which recognizes its binding legal force on the Union and on all Member States as of 2009.

The African Union (AU) adopted the African Charter on Human and Peoples' Rights (the Banjul Charter) in 1981, which reiterates the UDHR, ensures the right to property (Article 14), the right to work and equal pay for equal work (Article 15), the right to free disposal of wealth and natural resources (Article 21), and right to economic, social and cultural development (Article 22). While the African Commission on Human and Peoples' Rights may decide complaints against any of the 54 Member States, the African Court on Human and Peoples' Rights has jurisdiction to give advisory opinions and to decide complaints against the States that have accepted its jurisdiction.

As to the Americas, the Organization of American States (OAS) has ratified the American Declaration of the Rights and Duties of Man in 1948, the American Convention on Human Rights in 1969, and the Protocol of San Salvador in 1999. These legal documents guarantee the right to work, labor rights, education, as well as social security, healthy environment, health and the rights of the child. Together with the Inter-American Court of Human Rights installed in 1979, the InterAmerican Commission on Human Rights (IACHR) is one of the key institutions that is responsible for the region-based protection of human rights.

Adopted in 2012, the Association of Southeast Asian Nations (ASEAN) adopted the ASEAN Human Rights Declaration (AHRD), which affirms the importance of civil and political rights as well as economic, social and cultural rights, in the UDHR (Articles 10 and 26). With regards to economic rights, the AHRD gives emphasis on the eradication of child labor in the region and declares the right to work in favorable conditions, and the right to form and join trade unions (Article 27). The majority of the AHRD appears to have been influenced by the text of the ICESCR and ICCPR, albeit framed in a non-binding declaration. Furthermore, the ASEAN Inter-Governmental Commission on Human Rights (AICHR) was established as a consultative body in 2009 .

In the Middle East, "based on the faith of the Arab nation in the dignity of the human person", the League of Arab States (LAS) reaffirms "the principles of the Charter of the United Nations, the UDHR and the provisions of the ICCPR and the ICESCR" (Preamble of the Arab Charter of Human Rights). Adopted in 2004, the Arab Charter of Human Rights (ACHR) ensures that its citizens enjoy equality of opportunity in regard to work, as well as a fair wage and equal remuneration for work of equal value (Article $30 \& 32$ ) and prohibits forced labor with the exception of work under the terms of a court judgment (Article 31). It should be noted that all Member States of the LAS are party to more than one of the United Nations (UN) human rights treaties, including the two Covenants. Besides, the LAS established the Arab Commission on Human Rights in 1968 and the Arab Human Rights 
Committee in 2009 to monitor compliance with the ACHR. However, The Arab Charter does not provide for a complaint mechanism, but rather establishes a process through which the Committee receives and reviews state reports and makes recommendations.

\section{National constitutions}

The ratification of the UDHR Covenants facilitated the increase in the number of specific rights principles enshrined in various legally binding international documents (Jung, Hirschl and Rosevear, 2014). Many scholars confirm the clear impact of the international human rights instruments on national constitutions, demonstrating that the UDHR has served as a template for constitution makers (Elkins, Ginsburg and Simmons 2013). A number of constitutions (e.g. Argentina, Colombia, Costa Rica, Cyprus, Ecuador and Luxembourg) specifically refer to the UDHR. Accordingly, the majority of the world's constitutions, especially in Europe, Africa and Latin America, either include a wide range of socio-economic rights, sometimes as directly enforceable provisions, aspirational statements or directive principles.

Analyzing the status of economic and social rights in 195 contemporary national constitutions, Jung, Hirschl and Rosevear (2014) find that more than ninety percent of 195 constitutions worldwide currently in force contain at least one socioeconomic right. In regards to economic rights, including the right to form or join a trade union, the right to strike, to leisure, to a fair wage, to a healthy work environment, and to employment-derived social security, they reveal that "166 contain at least one of the six economic rights and more than half contain three or more; 134 constitutions contain at least one justiciable worker's right and 73 contain three or more" (Jung, Hirschl and Rosevear 2014, 1054). On social rights, their outstanding finding is the right to education being almost universal, while right to food and water is still very rare in national constitutions.

A relatively small number of constitutions lack a specific constitutional commitment to socio-economic rights. It should be noted that most of these constitutions have survived from before the 20th century. These countries are: Australia, Brunei, Canada, France, Israel, Kiribati, Lebanon, Liechtenstein, Malaysia, Micronesia, New Zealand, Singapore, Tonga, Trinidad and Tobago, the United States, and Vanuatu (Jung, Hirschl and Rosevear 2014, 1053). Nevertheless, Australia, Denmark, Finland and Sweden being prominent cases, socio-economic rights may be adopted by ordinary statute law and social welfare policies in the absence of specific constitutional recognition.

Upon closer inspection, the post-communist and Latin American states appear to have strong constitutional traditions with respect to economic and social rights. With the exception of the right to property, the rights to form or join a trade union and to education are present in all of the region's constitutions. The right to a fair wage is present in almost all countries except Belize. Workers' rights-fair wages, leisure, employment-derived social security, trade unions, and the right to strikeare present in more than eighty percent of constitutions in Latin America" (Jung, Hirschl and Rosevear 2014, 1075). In Southeast Asia, while Singapore and Malaysia have no economic and social rights at all, Philippines enshrines a wide range of justiciable rights. The Sub-Saharan African region ranks as having the third highest average number of economic and social rights per constitution and the South African Constitution is notable for its identification of human dignity as an 
underlying value and the explicit duty placed on the courts to interpret the rights protected under the UDHR (Grant 2015, 235). The right to food and water is not present in any Western European and North American constitutions, and they also have the lowest average number of workers' rights present per constitution. In the Middle East and North Africa, the national constitutions contain the lowest average incidence of justiciable rights with the exception of Turkey and Egypt and none of the Arab constitutions recognize the right to an adequate standard of living (Abdellatif 2004).

\section{Conclusion}

In the contemporary world order with neoliberal economic globalization as its organizing principle (Regilme 2014b; Harvey 2005), even traditionally robust welfare states in the global North are facing increasing challenges to provide the needed socio-economic benefits to their citizens. Amidst the threat of increasing automation that could displace many jobs, states such as Finland and the Netherlands, among many others, have seriously considered the prospect of providing unconditional universal basic income to all of its citizens. Such a prospective benefit could provide a guarantee to all entitled beneficiaries the needed income - regardless of employment status - in order to live a decent life. Yet, the increasing material inequality within and between states worldwide calls for more effective and legitimate interventions on the part of states and global governance institutions to provide the needed socio-economic benefits to the most marginalized individuals in order for them to live a decent and dignified life. While the right to economic dignity remains to be a widely entrenched principle in international law and in many constitutional traditions of states worldwide, the question remains how and under which conditions could individual governments and current global governance institutions effectively and legitimately provide the needed socioeconomic tools for all human beings to live a truly dignified life.

\section{References}

Abdellatif, A. (2004). Human Rights in the Arab Mediterranean Countries: Intellectual Discourse, Socio-Economic Background and Legal Instruments. Mediterranean Politics, 9(3), 319-343.

African Commission on Human and Peoples' Rights (1987). "African Charter on Human and Peoples' Rights”. http://www.achpr.org/instruments/achpr/

African Union. (1981). African Charter on Human and Peoples' Rights. Banjul: African Union.

Association of Southeast Asian Nations. (2012). ASEAN Human Rights Declaration.

Chenwi, L. (2013). Unpacking "progressive realisation", its relation to resources, minimum core and reasonableness, and some methodological considerations for assessing compliance. 46(3), 275-769. 
European Union. (2010). Charter of Fundamental Rights of the European Union. Official Journal of the European Union C83 (Vol. 53, p. 380). Brussels: European Union.

Grant, E. (2012). Human Dignity and Socio-Economic Rights. Liverpool Law Review, 33(3), 235-261.

Habermas, Jürgen. (2010) "The Concept of Human Dignity and the Realistic Utopia of Human Rights.” Metaphilosophy 41.4 464-480. Web.

Harvey, David. (2005). A Brief History of Neoliberalism. New York: Oxford University Press.

International Covenant on Economic, Social and Cultural Rights, Resolution 2200A (XXI). http://www.ohchr.org/EN/ProfessionalInterest/Pages/CESCR.aspx

International Labor Organization. (1944). Declaration concerning the aims and purposes of the International Labour Organisation (Declaration of Philadephia) http://blue.lim.ilo.org/cariblex/pdfs/ILO_dec_philadelphia.pdf

Jung, C., Hirschl, R., \& Rosevear, E. (2014). Economic and social rights in national constitutions. American Journal of Comparative Law, 62(4), 1043-1093.

League of Arab States. (2004). Arab Charter on Human Rights. Tunis: League of Arab States.

Organization of American States (1992). Appendix I: Additional Protocol to the American Convention on Human Rights in the Area of Economic, Social and Cultural Rights "Protocol of San Salvador". Netherlands Quarterly of Human Rights, 10(2), 232-242.

Regilme, Salvador Santino F Jr. (2014a). "The Social Science of Human Rights: the Need for a 'Second Image' Reversed?." Third World Quarterly 35(8): 1390-1405.

Regilme, Salvador Santino F Jr. (2014b). "Bringing the Global Political Economy Back in: Neoliberalism, Globalization, and Democratic Consolidation." International Studies Perspectives 15(3): 277-296.

United Nations (1948). "Universal Declaration of Human Rights". http://www.un.org/en/universal-declaration-human-rights/ 